УДК 338.518

DOI 10.15673/fie.v13i4.2217

Петренко О.П.

кандидат економічних наук, доцент кафедра економічної теорії

і економіки підприємства

Одеський державний аграрний університет

вул. Пантелеймонівська, 13, м. Одеса, Україна,65012 вул.Пантелеймонівська, 13, м. Одеса, Україна,65012 E-mail: Leka_m@ukr.net

ORCID ID: 0000-0001-9722-3785

\author{
Шевченко А.А. \\ кафедра економічної теорії \\ і економіки підприємства \\ E-mail: alisochka1978@gmail.com \\ ORCID ID: 0000-0002-3581-7884
}

кандидат економічних наук, доцент

\title{
ІНСТИТУЦІЙНЕ ЗАБЕЗПЕЧЕННЯ ДЕРЖАВНОГО УПРАВЛІННЯ У СФЕРІ ЗАЛУЧЕННЯ ІНВЕСТИЦІЙ В НАЦІОНАЛЬНУ ЕКОНОМІКУ
}

У статті розглянуто й оцінено основні актуальні проблеми інституційного забезпечення державного управління у сфері залучення інвестицій у національну економіку. Проаналізовано сучасний стан інвестиційної привабливості національної економіки. Досліджені та систематизовані напрями розвитку національної економіки на основі використання інноваційних рішень та наукомістких методологічних підходів. Обґрунтовано сукупність заходів, які реалізують завдання інституційного забезпечення державного управління у сфері залучення інвестицій у національну економіку. Запропоновано науково-практичні рекомендації щодо реалізації поточних та стратегічних орієнтирів удосконалення інституційного забезпечення державного управління у сфері залучення інвестицій у національну економіку. Доведено, що стратегічний курс у сфері забезпечення розвитку інвестиційної політики повинен розроблятись на засадах всеохоплюючого галузевого протекціонізму у контексті здійснення поступового переходу до вищої організації й ефективності галузей національної економіки з розвинутими виробничими силами, виробничими відносинами, налагодженим господарчим механізмом.

Ключові слова: інституційне забезпечення, інвестиції, інвестиційний процес, розвиток економіки, державне управління, інновації.

This work is licensed under a Creative Commons Attribution 4.0 International License http://creativecommons.org/licenses/by/4.0/

Постановка проблеми та її зв'язок з важливими науковими та практичними завданнями. В умовах стрімкого поширення кризових процесів у вітчизняній соціально-економічній системі й невизначеності зовнішнього середовища господарювання економіка потребує пожвавлення інвестиційних процесів з метою збереження й зростання ВВП, підвищення конкурентоспроможності вітчизняної продукції на внутрішньому й зовнішньому ринках та, загалом, забезпечення населення якісними, доступними якісними продуктами й послугами у достатній кількості, що є запорукою стабілізації ситуації у суспільстві. Недостатність власних ресурсів й непідготовленість національної економіки до роботи в умовах функціонування міжнародної конкуренції призвели до суттєвого зниження обсягів виробництва, старіння основних фондів, стрімкого погіршення фінансового стану суб’єктів господарювання.
Існуючі інституційні засади державного управління у сфері залучення інвестицій для розвитку національної економіки вимагають адаптації до умов глобалізації для безпосереднього використання в динамічних умовах економічного середовища. Потребують суттєвого поглиблення питання реалізації інституційних інструментів управління на основі використання інвестиційних ресурсів, підходи до визначення пріоритетності підприємств по залученню інвестицій, заходи регулювання розподілу цього виду ресурсів та ін.

Аналіз останніх публікацій по проблемі. Інституціональні зміни як найважливіший аспект сучасних соціально-економічних трансформацій широко досліджуються у вітчизняній економічній науці. Значний внесок у розробку теорії інституційних змін національної економіки внесли В. Базилевич, Н. Бутенко, 3. Варналій, Г. Ватаманюк, В. Геєць, С. Заха- 
рін, I. Малий, О. Прутська, О. Яременко. Сукупність питань, які пов'язані із аналізом проблем щодо інституційного забезпечення інвестиційної діяльності в національній економіці, знайшла відбиття в наукових публікаціях таких дослідників: І. Балабанов, Р. Бойко, О. Гарафонова, Б. Гриньов, К. Ілляшенко, П. Микитюк, С.С. Стоянова-Коваль, В. Онегіна, Л. Федулова та інші відомі вчені.

Незважаючи на широкий спектр напрямків дослідження особливостей інституційного регулювання інвестиційних процесів, у працях зазначених учених практично не знайшли відображення питання визначення теоретичних і практичних аспектів еволюційного розвитку інституційної системи економіки й, зокрема, стратегічних імперативів інституційного забезпечення державного управління у сфері залучення інвестицій у національну економіку, перебуває на початковій стадії й потребує додаткової уваги.

Формулювання цілей дослідження. Метою статті є дослідження перспективних напрямів удосконалення інституційного забезпечення державного управління у сфері залучення інвестицій у національну економіку.

Виклад основних результатів та їх обгрунтування. Україна визнана світовим співтовариством як країна 3 ринковою економікою. Останнім часом міжнародні рейтингові агентства регулярно повідомляють про підвищення кредитних рейтингів України й поліпшення прогнозів щодо стану макроекономічних показників національної економіки. Таким чином саме офшорні зони стають головним джерел для іноземних інвестицій в національну економіку. У свою чергу на фінансовому ринку приходять нові інвестори, а саме: пенсійні та страхові фонди [1].

Враховуючи сучасний стан розвитку національної економіки, нами було ідентифіковано сукупність нагальних проблем у сфері активізації інвести- ційних процесів, які потребують першочергового врегулювання:

- відсутність практично розвиненої інфраструктури у сфері обслуговування та підготовки інвестиційної пропозиції (відповідних консалтингових фірм для розробки технічної документації й економічного обгрунтування відповідних проєктів, представлених бізнес-планів, які розкривають алгоритм дій щодо просування та прийняття рішення у сфері узгодження й реалізації інвестиційних проєктів тощо);

- досить низький рівень інформаційноконсультаційного забезпечення діяльності інвесторів: адже інвестор перебуває під впливом ряду проблем щодо відсутності необхідної інформації про товари, земельні ділянки, приміщення, трудові ресурси тощо;

- не працює належним чином система супроводження інвестиційних проєктів, адже відсутні фахівці у сфері інвестиційного менеджменту на рівні підприємств та органах місцевого самоврядування [1].

Приєднання України до складу СОТ у 2008 р. насамперед сформувало необхідні передумови для налагодження інвестиційного клімату й мало слугувати позитивним сигналом для залучення іноземних інвесторів. Адже зобов'язання України на етапі приєднання безпосередньо стосувалися основних гарантій щодо захисту прав інвесторів. Україною було приведено національну систему звітності до встановлених міжнародних стандартів. Починаючи із 2013 р. ключовим для інвесторів повинно було стати підписання безпосередньо Угоди про асоціацію із $\mathrm{CC}$, однак відмова країни від проведення підписання стала ключовою причиною для стрімкого погіршення рівня індексу інвестиційної привабливості аж на 1,8 бала (рис. 1) [2]. Починаючи iз 2016 р. Свропейською Бізнес Асоціацією було відмічено покращення цього індексу до практично 2,9 балів (представленої за 5-бальною шкалою).

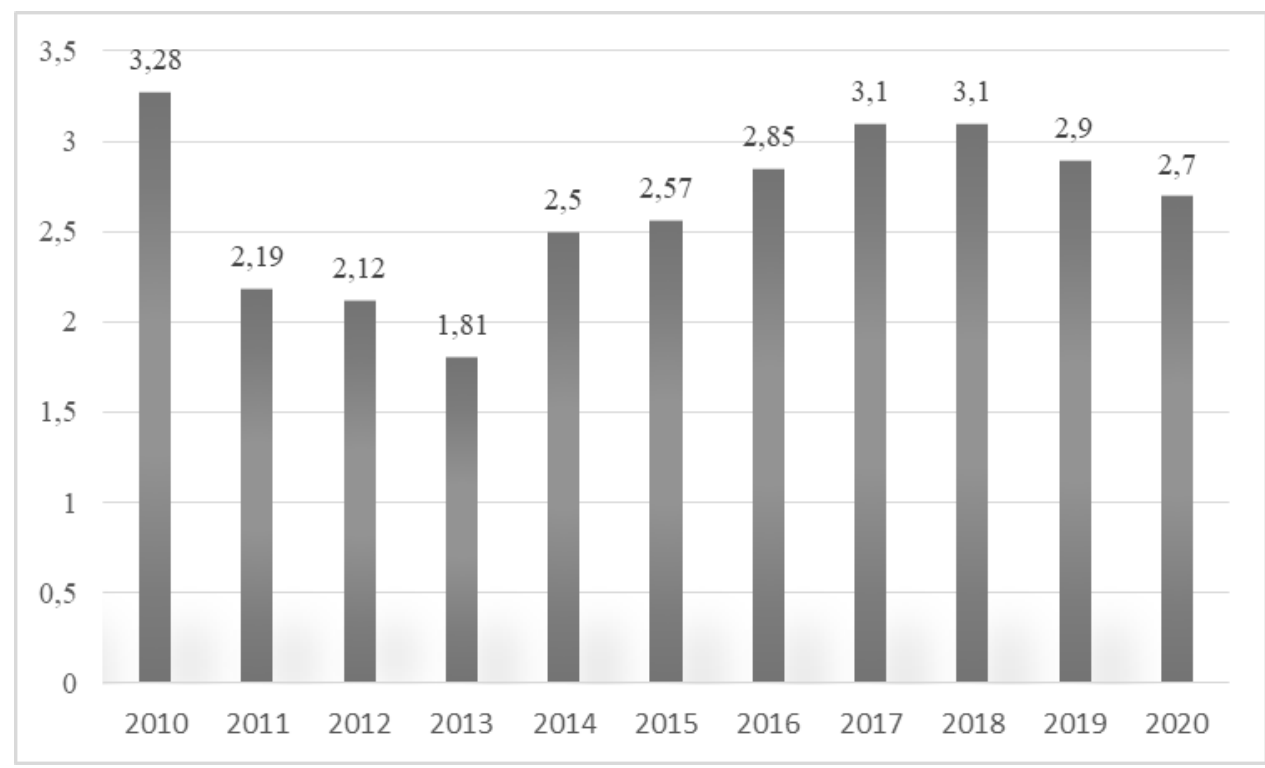

Рис. 1. Динаміка індексу інвестиційної привабливості за 2010-2020 роки (середнє значення) [2] 
Отримана оцінка не є звичайно високою, однак дає сподівання на перспективу у активізації іноземних інвесторів для України. Виходячи із проведеного аналізу бачимо, що структура іноземних інвестицій в Україні насамперед не є оптимальною цим самим не відповідаючи структурі інвестицій, які розміщені безпосередньо у значній більшості розвинених країн. Національній економіці актуальними є інвестиції із країн, які є безпосередньо технологічними лідерами, зазвичай «старих» країн-членів СС (насамперед це Франція, Італія і Німеччина), США і Японія, які є також лідерами у виробництві товарів із досить високою часткою представленої доданої вартості. Таким чином, для України у контексті введення у практичну дію Угоди про ПЗВТ із СС, тобто положень про нейтралізацію тарифних бар'єрів у налагодженні взаємної торгівлі відповідних країн-учасниць, стратегічними завданням $є$ побудова ефективних й гідних існуючому потенціалу України зв'язків із СС [2-3]. Також важливою $\epsilon$ й «якість» залучених ПІІ, тобто напрямів їх спрямування (рис. 2).

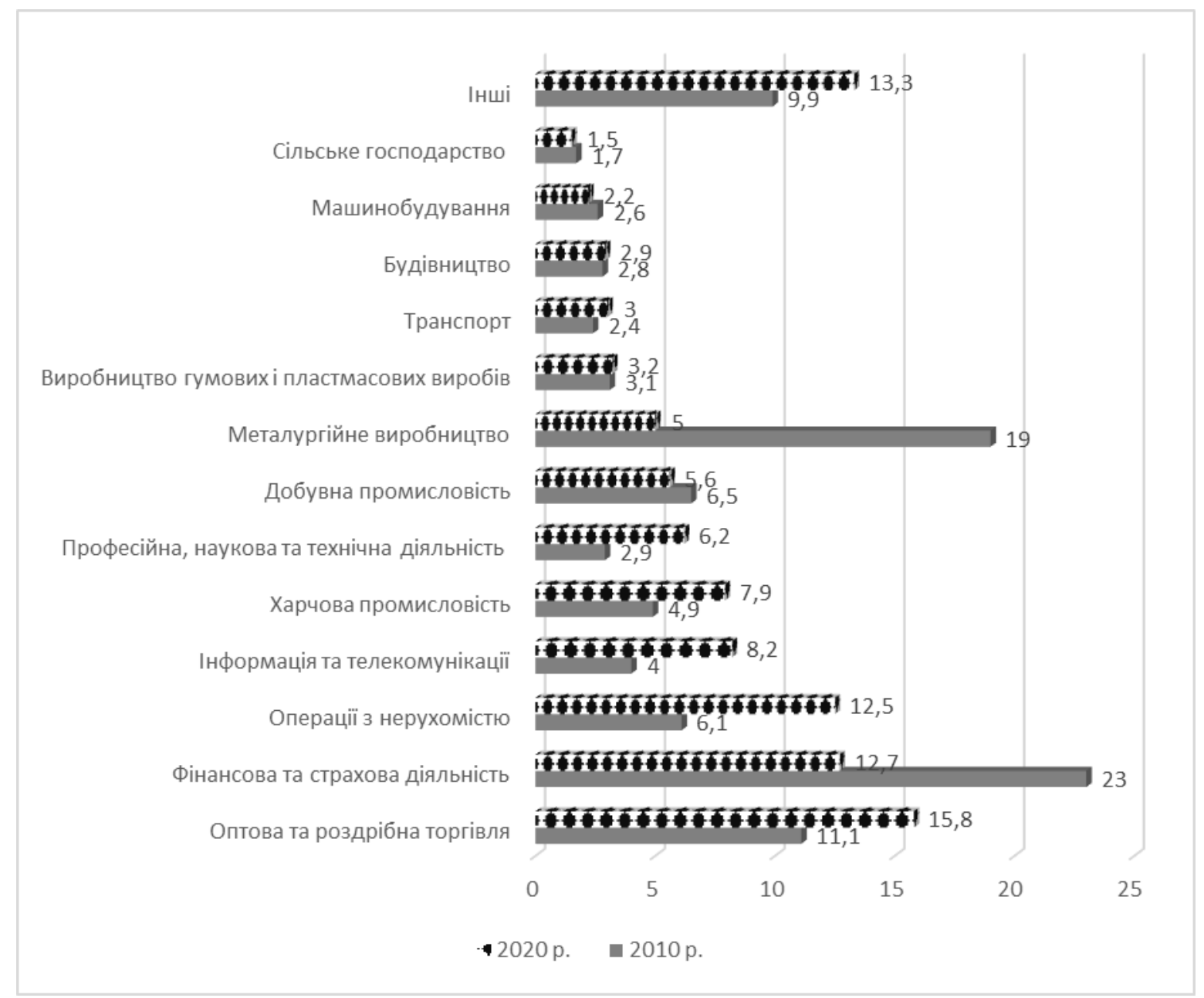

Рис. 2. Галузева структура розподілу ПІІ, у \% [2]

Незважаючи на те, що ПІІ практично присутні у різних галузях національної економіки, їх безпосередній розподіл не є належним чином збалансованим, тоді як сектори, які обираються іноземними інвесторами, зазвичай не відповідають сучасним соціально-економічним інтересам країни: тобто останніми роками ПІІ, що надходили в Україну все частіше булт орієнтовані на фінансову й торгівельну сфери, і все менше на розвиток реального сектору економіки.

Із кожним роком представлена галузева структура надходження ПІІ мала тенденцію до зміни. Інвестиційно привабливою насамперед для іноземних інвес- торів за 2019-2020 роки була саме промисловість: так на підприємствах промисловості станом на кінець 2020 р. було сконцентровано практично 11 595,9 млн дол (32,4 \%) ПІІ, із яких суттєва частка - 74 \% (8 609,3 млн дол) - зорієнтована на підприємства переробної промисловості. Зазвичай ПІІ направлено у виробництво різних продуктів харчування й споживчих товарів (таких марок: JTI, Phillip Morris, Procter \& Gamble, Nestle, Mondeles International) залишаючись привабливим для відповідних іноземних інвесторів на основі стабільного попиту. 
У свою чергу, іноземні інвестори в Україні насамперед орієнтуються на внутрішній ринок, а саме, сектори зі більш швидким обігом капіталу, що не пов'язані із зовнішньою торгівлею, а також не потребують довгострокових капіталовкладень та певним чином освоєння інноваційних технологій - оптову й роздрібну торгівлю (практично акумульовано 5 662,5 млн дол, або це 15,8 \% від загального обсягу), фінансову й страхову діяльність (4 557,6 млн дол, або це $12,7 \%$ ), й операції із нерухомим майном (4 495,7 млн дол, або це 12,5 \%).

Враховуючи проведений аналіз, нами обгрунтовано концептуальні підходи щодо формування напрямів інституційного забезпечення державного управління у сфері залучення інвестицій у національну економіку. Успішна реалізація таких напрямів насамперед залежить від забезпечення сталого розвитку національної економіки на основі імплементації наукомістких підходів та інноваційних рішень. Ключовими перспективними напрямками у такій сфері є:

- розробка інноваційних технологій та устаткування, що певним чином забезпечують глибоку, комплексну, енерго- й ресурсозберігаючу переробку для сільськогосподарської сировини на основі використання сучасних фізико-хімічних та електрофізичних способів (наприклад мембранні, екструзійногідролітичні, кавітаційні, гіпербаричні, біотехнологічні тощо) для розвитку екологічно безпечного виробництва важливих у соціальному аспекті продуктів із різними функціональними властивостями;

- генерування на основі інноваційних досягнень науки генетики, мікробіології, також нанотехнологій та інформатики, специфічних принципів технологій виробництва якісно нових, імпортозаміщуючих товарів та послуг зі орієнтованою зміною складу та властивостей;

- удосконалювання біотехнологічних процесів щодо переробки сільськогосподарської сировини, отримання нових видів продуктів підвищеної харчової та біологічної цінності із використанням високоактивних рекомбінантних і мутантних штамів й консорціумів мікроорганізмів;

- розробка наукових основ прижиттєвого формування заданих якісних і функціональних характеристик сировини тваринного й рослинного походження із метою створення диференційованих технологій іiі переробки та зберігання для забезпечення стабільної якості, практичної збереженості й мінімізації втрат цільової продукції;

- формування інтегральної системи моніторингу, організації управління, контролю за безпекою i якістю сировини й готових продуктів на різних етапах, включаючи виробництво, технологій зберігання, транспортування та напрямів реалізацію;

- налагодження механізму використання як вторинної сировини відходів від основного виробництва продуктів промислової переробки [4-5].

Як результат проведеного дослідження запропоновано сукупність заходів, які реалізують інституційні можливості нашої держави активізувати інвестиційні процеси в економіці, які будуть орієнтовані на її сталий розвиток відповідно до сформованих ринкових принципів та дієвого інституційного середовища, яке орієнтоване на активізацію інвестиційних процесах; стратегічних заходів у напрямку залучення банківського сектору до інституційного забезпечення державного управління у сфері залучення інвестицій у національну економіку (банків, інвестиційних компаній, державного і недержавних пенсійних фондів, різних страхових компаній й інших фінансових інститутів); стратегічні заходи щодо активізації безпосередньої участі іноземних інвесторів в інвестиційних процесах національної економіки (рис.3).

Оцінку ефективності реалізації визначених напрямів доцільно проводити на основі використання цільових індикаторів, які дозволяють відслідковувати динаміку розвитку національної економіки. У сучасних умовах прогресивний розвиток національної економіки та їі сировинної бази має відбуватися на основі аграрно-промислової інтеграції. Це має стати стратегічним курсом держави, націленим на докорінну, якісну трансформацію економіки. Підйом національної економіки на принципово новий організаційноекономічний рівень, інтенсифікація розвитку, досягнення світового рівня якості продукції, захист прав споживачів, продуктивності і ефективності виробництва є орієнтиром, рубежем розвитку [6-7].

Для реалізації стратегічних імперативів слід сформувати систему цілей розвитку з точки зору інтересів держави. Вищою ціллю інституційного забезпечення державного управління у сфері залучення інвестицій у національну економіку є задоволення соціально-економічних інтересів населення. Орієнтиром при цьому мають бути не норми споживання і не платоспроможний попит, а реальний попит. Важливо не тільки задовольнити населення продукцією у необхідній кількості, але й зробити іï доступною. Реалізація цієї цілі вимагає підвищення ефективності виробництва на основі використання досягнень науки, підвищення конкурентоспроможності економіки на внутрішньому й зовнішньому ринках [8]. 
META:

створення ефективної стратегії інституційного забезпечення державного управління у сфері залучення інвестицій у національну економіку

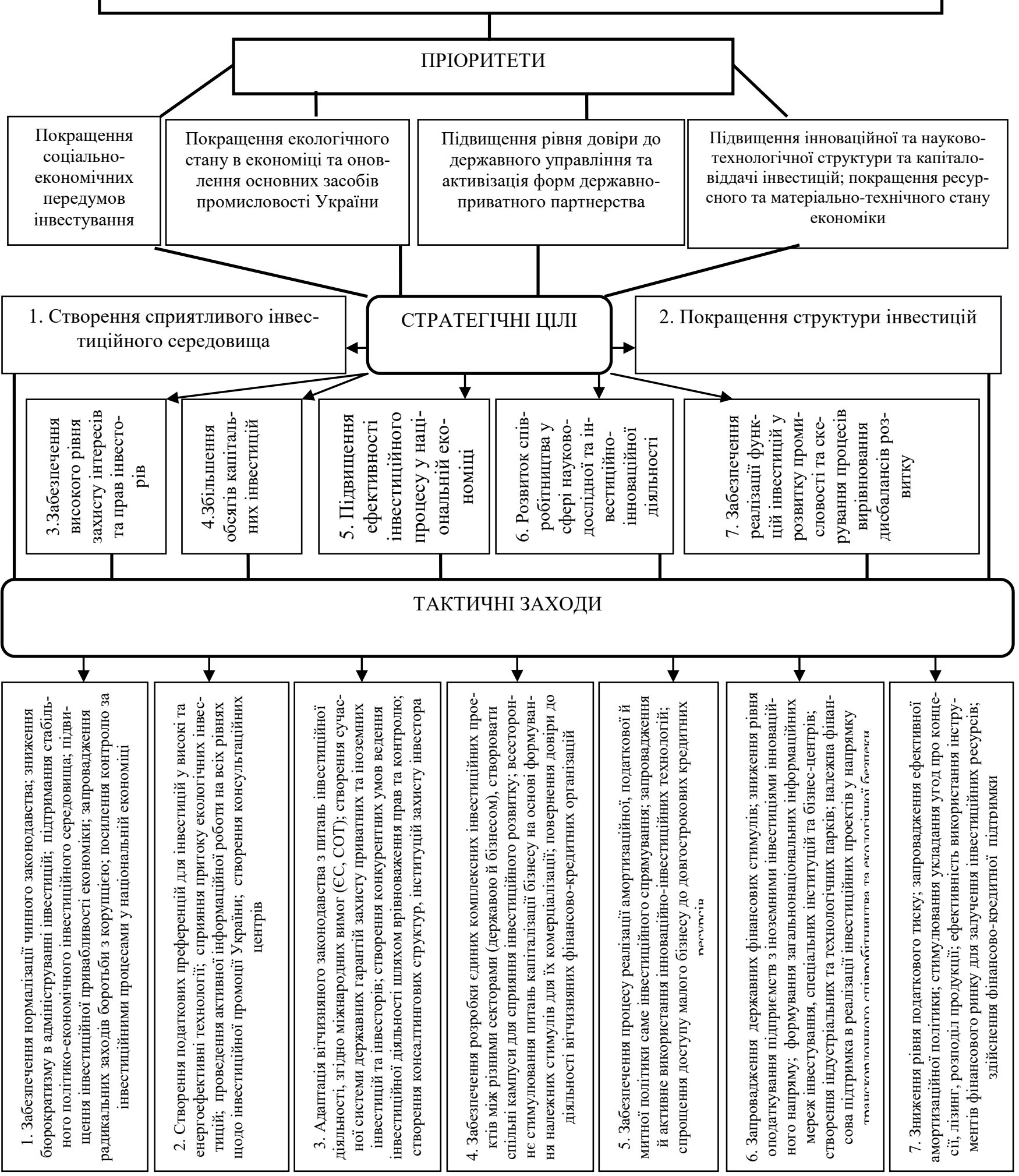

Рис. 3. Напрями удосконалення інституційного забезпечення державного управління у сфері залучення інвестицій у національну економіку*

*побудовано авторами 
Висновки та перспективи подальших досліджень. Успішна реалізація вищевикладених стратегічних рекомендацій щодо удосконалення інституційного забезпечення державного управління у сфері залучення інвестицій у національну економіку із урахуванням виявлених умов і факторів їх розвитку дозволить поліпшити постачання в національну економіку сучасної техніки в необхідній кількості високої якості; збільшити обсяги виробництва й реалізації послуг; активувати залучення інвестиційних ресурсів 3 недержавних джерел у розвиток інфраструктури, реконструкцію бізнесу; підвищити технікотехнологічний рівень виробництва; збільшити конкурентоспроможності товарів та послуг на міжнарод- ному ринку за рахунок освоєння інновацій. Перспективними напрямками дослідження інституційного забезпечення державного управління у сфері залучення інвестицій у національну економіку є такі: аналіз можливості застосування у вітчизняних реаліях преференційних заходів щодо залучення інвестицій у енергоефективні технології; визначення перспектив притоку екологічних іноземних інвестицій; формування ефективних інформаційних механізмів управління інвестиційними процесами в Україні; розробка інституційних засад для створення консультаційних центрів інвестиційного розвитку національної економіки.

\section{Література}

1. Василиця О.Б. Іноземне інвестування: загрози економічній безпеці України. Економіко-правовий часопис. 2016. Вип. 1. С. 12-22.

2. Офіційний сайт Державної служби статистики України. URL: http://www.ukrstat.gov.ua (дата звернення: 1.11 .2021$)$

3. Ткаченко Т., Шевчук Н., Гончарук І. Напрямки оптимізації інвестиційної діяльності підприємства // Агросвіт. 2017. № 7. С. 45-48.

4. Топ-менеджери погіршили оцінку інвестпривабливості України. EBA: веб-сайт. URL: https://eba.com.ua/top-menedzhery-pogirshyly-otsinku-investpryvablyvosti-ukrayiny (дата звернення: 1.11.2021)

5. Харчук С. А. Стан інвестиційної діяльності підприємств України в умовах економічної нестабільності // Економіка та держава. 2020. №1. С. 66-72. doi: 10.32702/2306-6806.2020.1.66

6. Бурлака Н.І. Розвиток інвестиційної діяльності підприємств України // Інвестиції: практика та досвід. 2019. № 8. C. 37-44. doi: 10.32702/2306-6814.2019.8.37

7. Міжнародний центр перспективних досліджень. Перспективні дослідження підготовлено Консорціумом Flemings/SARS. 2017. №11. C.25-36.

8. Оболенський О. Ю. Перспективи залучення прямих іноземних інвестицій у національну економіку // Економіка і регіон. 2014. № 3 (46). С. 8-14.

9. Кравчук А.О., Ніколюк О.В. Активізація інвестиційних процесів у контексті податкового навантаження національної економіки України // Наукові записки Інституту законодавства Верховної Ради України. 2017. № 4, C. 86-93. doi: 10.32886/instzak.2017.04.14

10. Добрянська Н.А., Ніколюк О.В., Карастаматі Т.О. Удосконалення організаційно-економічного механізму державного управління інвестиціями. // Сучасні проблеми державного управління в умовах системних змін. Сер. Державне управління: зб. наук. праць ДонДУУ. Маріуполь, 2018. Т. ХІХ, вип. 305. С. 183-192.

Стаття надійшла 9.11.2021

Стаття прийнята до друку 23.11.2021

Доступно в мережі Internet 30.12.2021

Petrenko O.

$\mathrm{PhD}$, Associate Professor

Department of Economic Theory and Economics of Enterprise

Odesa State Agrarian University

st. Pantelejmonivs'ka, 13, Odesa, Ukraine, 65012

E-mail: Leka m@ukr.net

ORCID ID: 0000-0001-9722-3785

\section{Shevchenko A}

$\mathrm{PhD}$, Associate Professor

Department of Economic Theory

and Economics of Enterprise

Odesa State Agrarian University

st. Pantelejmonivs`ka, 13, Odesa, Ukraine, 65012

E-mail: alisochka1978@gmail.com

ORCID ID: 0000-0002-3581-7884

Atamas G.

$\mathrm{PhD}$, Associate Professor

Department of Economics and Digital Business

Odessa State University of Intellectual Technologies and Communications

st. Kuznechna, 1, m. Odesa, Ukraine, 65023

E-mail: galya.atamas25@gmail.com

ORCID ID: 0000-0002-2830-1580

\section{INSTITUTIONAL SUPPORT OF PUBLIC ADMINISTRATION IN THE FIELD OF ATTRACTING INVESTMENT INTO THE NATIONAL ECONOMY}

The article considers and assesses the main current problems of institutional support of public administration in the field of attracting investments into the national economy. The current state of investment 
attractiveness of the national economy has been analyzed. It has been proved that the structure of foreign investment in Ukraine is not optimal and does not correspond to the structure of investments, which are located directly in the vast majority of developed countries. It has been established that the main negative factors that investors focus on today are: high levels of corruption, rather weak judicial system, labor migration, pressure from law enforcement agencies, low level of debureaucratization of business processes, use of "turbo mode" in the work of the legislative branch of government. The main positive aspects of attracting investment into the national economy are: coordinated stabilization of the socio-political situation, intensification of reforms in the land market, updating the tools of the concession mechanism, the functioning of the Supreme Anti-Corruption Court, abolition of dividend repatriation limits. The necessity of deepening the issue of implementation of institutional management tools based on the use of investment resources, approaches to determining the priority of enterprises to attract investment, measures to regulate the distribution of this type of resources and more have been substantiated. The directions of development of the national economy on the basis of knowledge-intensive approaches and innovative solutions have been researched and systematized. A set of measures that implement the tasks of institutional support of public administration in the field of attracting investment into the national economy has been substantiated. Scientific and practical recommendations for the implementation of current and strategic guidelines for improving the institutional support of public administration in the field of attracting investment into the national economy have been offered. The strategic course of the state should include making the transition to higher organization and efficiency of the branches of the national economy with developed productive forces, production relations, and an established economic mechanism on the basis of sectoral protectionism.

Key words: institutional support, investments, investment process, economic development, public administration, innovations.

\section{References}

1. Vasylytsia, O. B. (2016). Inozemne investuvannia: zahrozy ekonomichnii bezpetsi Ukrainy. Ekonomikopravovyi chasopys, (1), 12-22.

2. Ofitsinyi sait Derzhavnoi sluzhby statystyky Ukrainy. Retrieved November 1, 2021, from http://www.ukrstat.gov.ua

3. Tkachenko, T., Shevchuk, N., \& Honcharuk, I. (2017). Napriamky optymizatsii investytsiinoi diialnosti pidpryiemstva. Ahrosvit, (7), 45-48

4. Top-menedzhery pohirshyly otsinku investpryvablyvosti Ukrainy. EBA. (2019, July 2). Retrieved November 1, 2021, from https://eba.com.ua/top-menedzhery-pogirshyly-otsinku-investpryvablyvosti-ukrayiny

5. Kharchuk, S. A. (2020). Stan investytsiinoi diialnosti pidpryiemstv Ukrainy v umovakh ekonomichnoi nestabilnosti. Ekonomika ta derzhava, (1), 66-72. doi: 10.32702/2306-6806.2020.1.66

6. Burlaka, N. I. (2019). Rozvytok investytsiinoi diialnosti pidpryiemstv Ukrainy. Investytsii: praktyka ta dosvid, (8), 37-44. doi: 10.32702/2306-6814.2019.8.37

7. Mizhnarodnyi tsentr perspektyvnykh doslidzhen. Perspektyvni doslidzhennia №11. (2017). Pidhotovleno Konsortsiumom Flemings/SARS, 25-36.

8. Obolenskyi, O. Yu. (2014). Perspektyvy zaluchennia priamykh inozemnykh investytsii u natsionalnu ekonomiku. Ekonomika i rehion, (3 (46)), 8-14.

9. Kravchuk, A. O., \& Nikoliuk, O. V. (2017). Aktyvizatsiia investytsiinykh protsesiv u konteksti podatkovoho navantazhennia natsionalnoi ekonomiky Ukrainy. Naukovi zapysky Instytutu zakonodavstva Verkhovnoi Rady Ukrainy, (4), 86-93. doi: 10.32886/instzak.2017.04.14

10. Dobrianska, N. A., Nikoliuk, O. V., \& Karastamati, T. O. (2018). Udoskonalennia orhanizatsiinoekonomichnoho mekhanizmu derzhavnoho upravlinnia investytsiiamy. Suchasni problemy derzhavnoho upravlinnia $v$ umovakh systemnykh zmin, (305), 183-192.

Received 9 November 2021

Approved 23 November 2021

Available in Internet 30.12.2021

Цитування згідно ДСТУ 8302:2015

Петренко О.П., Шевченко А.А., Атамась Г.П. Інституційне забезпечення державного управління у сфері залучення інвестицій в національну економіку // Економіка харчової промисловості. 2021. Т. 13, вип. 4. С. 41-47. doi 10.15673/fie.v13i4.2217

Cite as APA style citation

Petrenko, O., Shevchenko, A., \& Atamas, G. (2021). Institutional support of public administration in the field of attracting investment into the national economy. Food Industry Economics, 13(4), 41-47. doi 10.15673/fie.v13i4.2217 